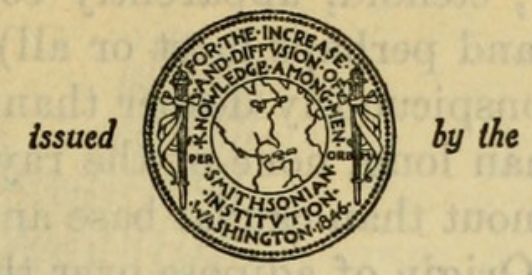

SMITHSONIAN INSTITUTION

U. S. NATIONAL MUSEUM

Vol. 97

Washington : 1947

No. 3211

\title{
A NEW GENUS AND SPECIES OF DEEP-SEA FISH OF THE FAMILY MYCTOPHIDAE FROM THE PHILIPPINE ISLANDS
}

\section{By Robert R. Miller}

Tue depths of the oceans have yielded forms of life that have long been of interest to biologists and that have fascinated scientists and laymen alike. A great variety of deep-sea fishes has been described, many of them grotesque in form and provided with highly specialized organs that adapt them for life in utter darkness. Our knowledge of a considerable number of these fishes is based only on single specimens, and quite often these were imperfect. Hence the precise systematic position of some genera, and even families, is not uncommonly in doubt (Chapman, 1939, p. 508; Parr, 1945, p. 127; Myers, 1946).

The novelty about to be described was collected by the Albatross during 1908-1909, on her Philippine cruise, and is based upon 31 specimens of graded sizes, a number of which are nearly perfectly preserved. This fortunate circumstance has permitted a far more complete description than is usually possible with deep-sea forms. Although taken nearly three-fourths of a mile beneath the surface, this fish shows few adaptations for abyssal life.

\section{SOLIVOMER, new genus}

Genotype.-Solivomer arenidens, new species.

Diagnosis.-Body elongate, moderately compressed, broadly oval in cross section, widest across head, deepest just behind occiput, from which it tapers gradually to caudal fin. Scales on body large (41 
or 42 in lateral line), ctenoid, apparently covering the head also, where at least some (and perhaps most or all) of them are cycloid; those in lateral line conspicuously deeper than surrounding scales.

Dorsal fin higher than long, none of the rays produced, its origin a little nearer tip of snout than caudal base and almost directly over insertion of pelvics. Origin of adipose over that of anal fin, its free margin slightly fimbriate. Anal higher than long, its origin a little more than $1 \frac{1}{2}$ times nearer caudal base than insertion of pelvics. Pectorals lateral, inserted low (much nearer belly than lateral line), with narrow basis, the middle rays long and slender. Pelvics abdominal, 8-rayed. Caudal fin well developed, moderately forked, free from anal.

No photophores. Air bladder present. Pseudobranchiae rudimentary. Anus just before anal fin.

Maxillary extending beyond eye a distance about equal to diameter of eye, greatly dilated posteriorly, slipping under preorbital anteriorly; provided with a single slender supplementary maxillary, about one-third length of maxillary. Premaxillary long, slender, forming entire outer margin of upper jaw. Dentary broadest at symphysis, tapering gradually posteriorly.

Teeth finely granular, covering inner and outer surfaces of both jaws (except at the symphyses) so that they are clearly visible when the mouth is closed. Vomer angular, not indented at apex where it is widest, covered by finely granular teeth (fig. 2) ; same kind of teeth on the long, slender, tapering palatines and on the rounded entopterygoids. Tongue small, toothless, bound-down at the tip, with finely granular teeth on the long, narrow basihyal.

Branchiostegals usually 10 (9 on the right side in 2,11 on the left side in 1, out of 29 specimens counted), slender, curved, becoming progressively more flattened from lowermost to uppermost. Gill membranes attached far forward, free from isthmus. Gill rakers on first arch rather long, slender, denticulate; those on succeeding arches shorter and spinulate at their tips.

Mesethmoid with a low, median ridge. Palatine with anterior end attached to vomer by a ligament, with a process directed upward and outward that overlaps the proximal end of the maxillary and is supported by a lateral projection of the mesethmoid. Parasphenoid extending upward to the frontals between the lateral ethmoids (Regan, 1911, pp. 121, 128).

The technical characters of Solivomer agree closely enough with those used to delimit the family Myctophidae (Regan, 1911; Parr, 1928; Bolin, 1939) that I refer it to that group of fishes. The lack of specializations, such as photophores, and the general normal appearance of the new genus suggest that it is a primitive form low in the evolutionary line along which the myctophids have advanced 


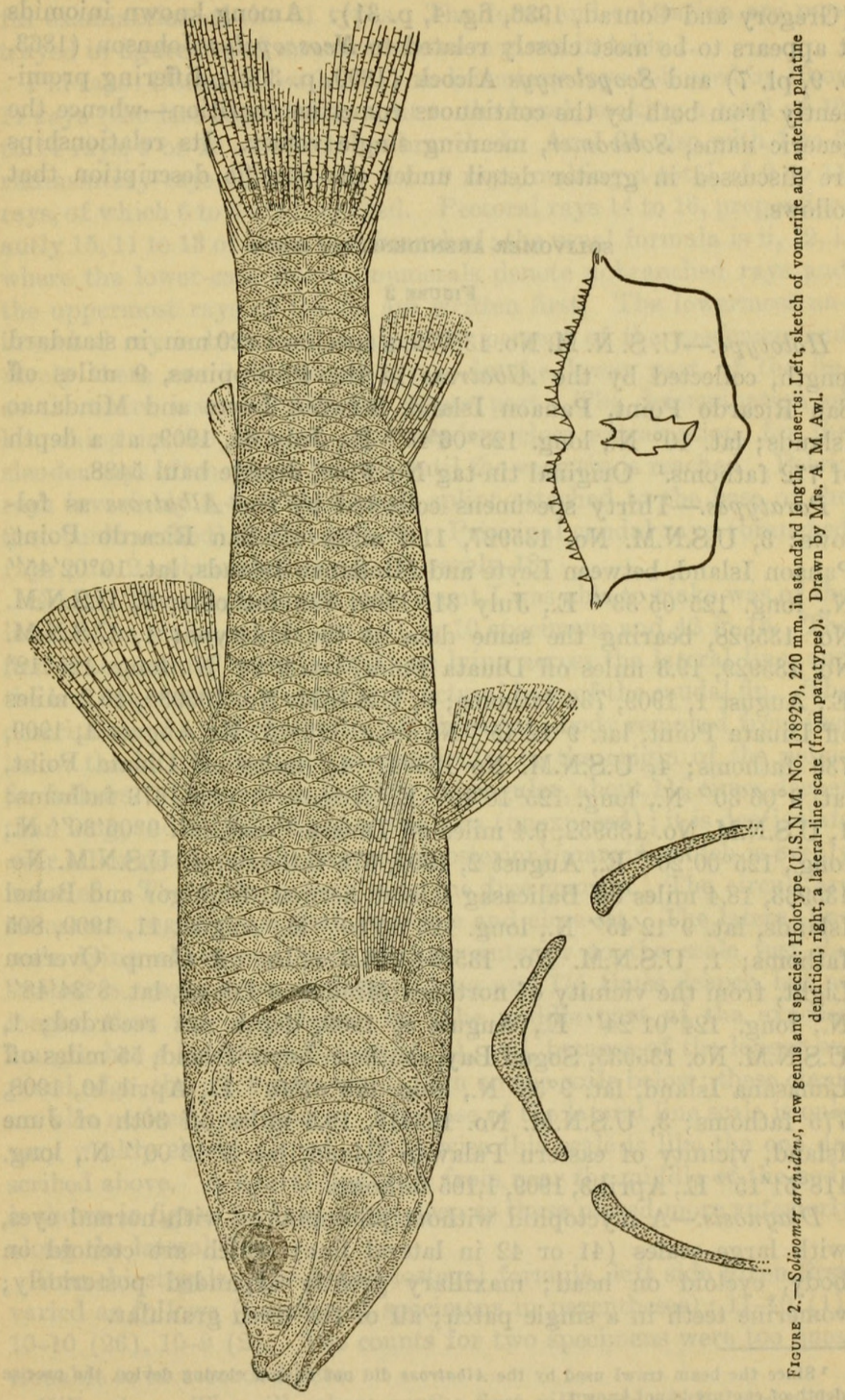


(Gregory and Conrad, 1936, fig. 4, p. 31). Among known iniomids it appears to be most closely related to Neoscopelus Johnson (1863, p. 9, pl. 7) and Scopelengys Alcock $(1890$, p. 302$)$, differing prominently from both by the continuous vomerine dentition-whence the generic name, Solivomer, meaning single vomer. Its relationships are discussed in greater detail under the specific description that follows.

\section{SOLIVOMER ARENIDENS, new species}

FIGURe 2

Holotype.-U. S. N. M. No. 138929 , a specimen $220 \mathrm{~mm}$. in standard length, collected by the Albatross in the Philippines, 9 miles off San Ricardo Point, Panaon Island, between Leyte and Mindanao Islands; lat. $10^{\circ}$ N., long. $125^{\circ} 06^{\prime} 45^{\prime \prime}$ E., July 31 , 1909, at a depth of 772 fathoms. $^{1}$ Original tin-tag No. 9168, dredge haul 5488.

Paratypes.-Thirty specimens collected by the Albatross as follows: 3, U.S.N.M. No. 135927, 11.2 miles off San Ricardo Point, Panaon Island, between Leyte and Mindanao Islands, lat. $10^{\circ} 02^{\prime} 45^{\prime \prime}$ N., long. $125^{\circ} 05^{\prime} 33^{\prime \prime}$ E., July 31, 1909, 732 fathoms; 9, U.S.N.M. No. 135928, bearing the same data as the holotype; 1, U.S.N.M. No. $135929,19.3$ miles off Diuata Point, lat. $9^{\circ} 24^{\prime}$ N., long. $125^{\circ} 12^{\prime}$ E., August 1, 1909, 736 fathoms; 3, U.S.N.M. No. 135930, 15.2 miles off Diuata Point, lat. $9^{\circ} 12^{\prime} 45^{\prime \prime}$ N., long. $125^{\circ} 20^{\prime}$ E., August 1, 1909, 735 fathoms; 4, U.S.N.M. No 135931, 4.2 miles off Diuata Point, lat. $9^{\circ} 06^{\prime} 30^{\prime \prime}$ N., long. $125^{\circ} 18^{\prime} 40^{\prime \prime}$ E., August 2, 1909, 678 fathoms; 1, U.S.N.M. No. 135932 , 9.4 miles off Diuata Point, lat. $9^{\circ} 06^{\prime} 30^{\prime \prime}$ N., long., $125^{\circ} 00^{\prime} 20^{\prime \prime}$ E., August 2, 1909, 976 fathoms; 4, U.S.N.M. No. 135933, 18.4 miles off Balicasag Island, between Siquigor and Bohol Islands, lat. $9^{\circ} 12^{\prime} 45^{\prime \prime}$ N., long. $123^{\circ} 45^{\prime} 30^{\prime \prime}$ E., August 11, 1909, 805 fathoms; 1, U.S.N.M. No. 135934, 24.6 miles off Camp Overton Light, from the vicinity of northern Mindanao Island, lat. $8^{\circ} 34^{\prime} 48^{\prime \prime}$ N., long. $124^{\circ} 01^{\prime} 24^{\prime \prime}$ E., August 8, 1909, depth not recorded; 1, U.S.N.M. No. 135935, Sogud Bay, southern Leyte Island, 55 miles off Limasana Island, lat. $9^{\circ} 58^{\prime}$ N., long. $125^{\circ} 07^{\prime} 40^{\prime \prime}$ E., April 10, 1908, 775 fathoms; 3, U.S.N.M. No. 135419, 19.5 miles off 30th of June Island, vicinity of eastern Palawan Island, lat. $9^{\circ} 13^{\prime} 00^{\prime \prime} \mathrm{N}$., long. $118^{\circ} 51^{\prime} 15^{\prime \prime}$ E., April 3, 1909, 1,105 fathoms.

Diagnosis.-A myctophid without photophores, with normal eyes, with large scales (41 or 42 in lateral line) which are ctenoid on body, cycloid on head; maxillary greatly expanded posteriorly; vomerine teeth in a single patch; all of the teeth granular.

${ }^{1}$ Since the beam trawl used by the Albatross did not have a closing device, the precise depth of capture is not known. 
Description.-The following description is based largely on a careful examination of the 31 types. The form and coloration are portrayed in figure 2, and measurements are given in table 1.

Fin rays: Dorsal fin with 1 to 3 rudimentary rays followed by 10 or 11 rays (the last regarded as split to the base), making a total of 12 to 14 rays, 9 or 10 of which are branched. Anal fin also with 1 to 3 rudimentary rays followed by 7 to 9 rays, making a total of 9 to 11 rays, of which 6 to 8 are branched. Pectoral rays 14 to 16 , preponderantly 15,11 to 13 of these rays branched; the usual formula is ii, 12, i, where the lower-case Roman numerals denote unbranched rays and the uppermost rays of the fin are written first. The lowermost unbranched ray is branched in about 16 percent of the specimens and rarely there are 2 unbranched rays in the lower part of the fin, as there are invariably in the upper part. The determination of branching in the pectoral rays requires close examination, for the slender rays often do not branch until the very tip is reached. Pelvic rays invariably $8-8$, with a small splint attached to the base of the first (unbranched) ray in each fin. Principal caudal rays (branched rays plus 2 unbranched rays) 19, rarely 18 .

Scales: The only accurate scale count I was able to make was of the lateral-line scales, which were 41 in 10 specimens and 42 in 15. The first scale counted was the first one lying across the lateral line, and the last one recorded was at the structural base of the caudal fin. The description of a scale from the left side of the body removed from just below the lateral line and perpendicular to the origin of the pelvic fin follows. This scale is roughly rectangular, about $1 \frac{1}{3}$ times deeper than long, and shield-shaped at the base (unexposed); it is denticulate over all or nearly all the exposed (posterior) margin, which is evenly rounded. The focus is very near the free margin. The circuli are numerous, regularly spaced, very fine and close-set. The lateral-line scale lying above and very slightly anterior to the scale just described is nearly twice as deep as long and $1 \frac{1}{2}$ times deeper, but no longer, than the scale below it. The middle part of the exposed margin has a broad notch (see fig. 2), and, because of the longer exposed edge, there are more ctenii than on the scale below; these ctenii are also noticeably stronger. The base of the lateral line scale is only very weakly shield-shaped. Otherwise this scale is like the one described above. A lateral-line scale from near the middle of the body is shown in figure 2. It is not so deep as those placed more anteriorly along the lateral line.

Branchiostegals: The branchiostegal formula, left side given first, varied as follows (number of specimens in parentheses) : 11-10 (1), 10-10 (26), 10-9 (2). The counts for two specimens were too questionable to be recorded here.

Gill rakers: The gill rakers on the first gill arch of the right side 
were counted on 20 specimens. There were 4 or, usually, 5 rakers on the upper limb, 13 or 14 on the lower limb, and 1 at the angle of the arch, making a total of 18 to 20 , usually 19 or 20 .

A detailed description of the detention of Solivomer, as well as of certain osteological and other characters, has already been given under the generic diagnosis.

The following proportional measurements with precision dividers were made on 10 specimens grading in size (standard length) from 98 to $270 \mathrm{~mm}$. In standard length: Greatest depth of body 4.15 to 4.5 ; head length 2.8 to 3.05 ; caudal peduncle length 5.9 to 6.7 . In head length: Head depth 1.45 to 1.6 ; head width 2.2 to 2.4 ; snout 4.1 to 4.4 ; eye 6.0 to 7.0 ; width of bony interorbital $4.5-5.1$; maxillary length 1.55 to 1.75 ; mandible length 1.5 to 1.6 ; least depth of caudal peduncle 3.25 to 4.0 ; length of pectoral fin 1.3 to 1.55 ; length of pelvic fin 1.7 to 2.2 ; postorbital length 1.55 to 1.65 ; length of depressed dorsal fin 1.3 to 1.45 ; length of depressed anal fin 2.05 to 2.35 . Greatest width of maxillary 1.1 to about 1.4, usually 1.1 or 1.2 , in diameter of eye. Origin of dorsal fin nearer snout than caudal base by a distance varying between the diameter of the eye to the diameter of the orbit. Origin of anal fin much nearer caudal base than insertion of pelvics by a distance varying between the snout length to about one-half the length of the maxillary (as measured anteriorly to the tip of the premaxillary).

The general coloration of the new genus, after 37 or 38 years in preservation, is a rather uniform brown except for the opercular membrane which is brownish black in many specimens. Many of the scale centers are light yellow or yellow-brown and the scale margins are dark brown. The basal portions of all the fins, particularly along the interradial membranes of the dorsal and anal fins, are dark brown. This type of pigmentation extends outward a considerable distance on the caudal fin, fading distally. Similar dark-brown pigment occurs between the anterior and posterior bony rims of the preopercle and along the lower margins of the mandibles. Around the orbits of several specimens are delicate, irregular narrow lines of dark pigment usually nearly vertical with the body axis. The same type of lines are found on the top of the head, running obliquely away from the midline on each side.

Comparisons and relationships.-Solivomer differs from all other known genera of the Myctophidae, except Scopelengys, in lacking photophores. That monotypic genus, though known only from a few specimens, also lacks these organs. At first sight the resemblances between Solivomer and Scopelengys are very striking. The general body form, oblique mouth, wide of gape, general shape and position of fins, slender supramaxillary, extent of dentition, and rudimentary pseudobranchiae are remarkably alike in the two genera. The sharp 
difference in the nature of the teeth, granular in Solivomer and villiform in Scopelengys, and in particular the very different vomerine dentition-in a continuous, angular patch in Solivomer (fig. 2) in contrast to two separate patches in Scopelengys-clearly indicate generic separation. Regan (1911, pp. 125, 128) used the general vomerine dentition (teeth in two well-separated patches) as a family character for both the Sudidae and Myctophidae, but Parr (1928, p. 16) found that Notosudis has more or less continuous vomerine teeth, and Bolin (1939, p. 113) noted a similar condition in the myctophid Hygophum. Chapman (1939, pp. 520,523) has described similar dentition in Sudis squamosa and Lestidium (or Bathysudis) parri.

In addition to these sharp differences Solivomer differs further from Scopelengys in having (1) ctenoid rather than cycloid body scales; (2) 10 rather than 8 branchiostegals; (3) the anal fin farther back, so that the origin of the adipose fin lies over the origin, rather than over the last rays, of the anal fin; (4) principal dorsal rays 10 or 11 rather than 11 or 12 ; (5) principal anal rays 7 to 9 rather than 11 to $13 ;(6)$ eyes normal rather than reduced; (7) mouth less oblique; and (8) preorbital narrower.

Just as this paper was finished, a specimen of Scopelengys tristis was discovered by chance while moving some jars of unidentified fishes in the National Museum. The retention of three scales on this fish gives us, as far as I am aware, the first information on the squamation of Scopelengys. The best-preserved scale is embedded and lies along the midline of the right side of the body, just anterior to the origin of the anal fin. It is cycloid, oval, deeper than long, and lacks radii. The greatest length is about $6.2 \mathrm{~mm}$., the greatest width approximately $4.2 \mathrm{~mm}$., and the focus is far away from the scale center-apparently near the exposed end of the scale, as in Solivomer. The circuli are widely spaced near the center, showing typically rapid initial growth, but are regularly spaced from there to the scale margin, thus indicating uniform water temperature which is to be expected at great depths. Two other scales, loosely attached, are similar in structure and general form to the one just described but differ in shape as do scales from different parts of the body. One, the largest, lies near the dorsal base on the right side of the body; the other, much smaller, lies near the anal base on the left side of the body. From the size of these scales and the retention of most of the scale pockets, it is possible to estimate that this specimen of Scopelengys had about 32 scales along the lateral line. Thus the scales are larger than in Solivomer, which has more than 40 along the lateral line. The standard length of this specimen is about $135 \mathrm{~mm}$. It bears U.S.N.M. No. 132459 and represents an extension in the known range of the genus. The precise location of 
capture is in doubt, however, for there were two loose labels in the jar containing this fish. It was collected by the Albatross on November 19 or 22,1904 , at either station 4669 or 4675 . Both of these stations lie off Callao, Peru, ${ }^{2}$ station 4669 at latitude $12^{\circ} 13^{\prime}$ S., longitude $80^{\circ} 25^{\prime}$ W., and station 4675 at latitude $12^{\circ} 54^{\prime}$ S., longitude $78^{\circ} 33^{\prime} \mathrm{W}$. The known range of the genus Scopelengys may now be stated as the Arabian Sea and the Pacific coast of Mexico, Central America, and South America. Norman $(1939$, p. 28$)$ recently recorded new material from the Arabian Sea.

Parr (1928, pp. 47-48) divided the Myctophidae into three subfamilies, Scopelenginae, Neoscopelinae, and Myctophinae, principally on the basis of the presence or absence of photophores and their arrangement when present. Following this system, Solivomer would fall into the Scopelenginae, but as the new genus obviously forms an independent line it is possible that it should be placed in a separate subfamily. The continuous vomerine dentition, as well as the granular nature of the teeth, could be used to justify subfamily ranking. For similar reasons, Parr (1928, p. 16) regarded Notosudis of the Sudidae as comprising a distinct subfamily. Without further study, however, particularly of the osteology of the genera of myctophid fishes, I hesitate to add another subfamily to the list.

Solivomer combines a number of primitive or generalized features with some specialized ones, which suggests that it is close to, but not in direct line with, the basic type from which the Myctophidae may have evolved. Gregory and Conrad (1936, fig. 4, p. 31) chose Neoscopelus to represent the primitive myctophid and $I$ agree that this genus is a generalized representative. It differs most conspicuously from both Solivomer and Scopetengys in possessing photophores in the belly region (and also under the free tip of the tongue), and in the following features it appears to be somewhat more specialized than Solivomer: (1) vomerine teeth in two broadly connected patches-a character that appears to have been generally overlooked, for these teeth, when present in the Myctophidae, are generally described as being in two well-separated patches; and (2) 9 rather than 10 branchiostegals. Probably all three of these genera, Solivomer, Scopelengys, and Neoscopelus, represent offshoots from the base stem of the Myctophidae, with Solivomer and Neoscopelus nearer the generalized stock than Scopelengys.

One-eyed specimen.-Of the 31 specimens of Solivomer arenidens available to me, all except one are normal-eyed. One adult paratype,

\footnotetext{
2 The possibility that the specimen was taken in the Alexander Archipelago of Alaska seems remote but should be mentioned. A third label in the jar, loosely but definitely wrapped in paper with some other fishes, reads "Dr. 4749 Aug. 29, 05 Albatross." This locality is at lat. $55^{\circ} 33^{\prime}$ N., long. $131^{\circ} 51^{\prime} 48^{\prime \prime}$ W.
} 
U.S.N.M. No. $135935,225 \mathrm{~mm}$. in standard length, has a fully developed right eye but the left eye is atrophied. The left orbit is developed but is completely closed over by skin and scales to form a concave pocket through which no part of the eye is visible. Otherwise, this fish appears to be perfectly normal.

Range.-The new genus is so far known only from the material listed herein (see sections on "Holotype" and "Paratypes"), all of which came from various islands in the Philippines.

Etymology.-The specific name arenidens, meaning "sand tooth," refers to the sandpaperlike dentition. Solivomer refers to the single patch of vomerine teeth.

Acknowledgments.-In working out certain osteological characters of Solivomer I received the generous assistance of Dr. Leonard P. Schultz. Dr. Carl L. Hubbs kindly suggested the generic and specific names.

TABLE 1.-Measurements of Solivomer arenidens expressed in thousandths of the standard length

\begin{tabular}{|c|c|c|c|c|c|c|c|c|c|c|c|}
\hline \multirow{2}{*}{$\frac{\text { Character }}{\text { Standard length, } \mathrm{mm}}$} & \multirow{2}{*}{$\frac{\begin{array}{c}\text { Holo- } \\
\text { type }\end{array}}{220}$} & \multicolumn{10}{|c|}{$\begin{array}{ll}\text { Paratypes } \\
\end{array}$} \\
\hline & & 282 & 251 & 243 & 230 & 210 & 178 & 165 & 144 & 103 & 97 \\
\hline Dorsal origin to tip of snout.. & 479 & 476 & 480 & 478 & 476 & 480 & 483 & 490 & 484 & 473 & 484 \\
\hline Tip of & 349 & 294 & 332 & 348 & 334 & 345 & 352 & 345 & 341 & 343 & 335 \\
\hline & 491 & 467 & 462 & 494 & 466 & 483 & 482 & 482 & 64 & 461 & 451 \\
\hline Tip & 789 & 789 & 783 & 790 & 791 & 798 & 784 & 776 & 805 & 776 & 799 \\
\hline & 820 & 787 & 811 & 807 & & & 803 & 812 & 90 & 769 & 770 \\
\hline Ans & 2 & 227 & 229 & 223 & 233 & & 232 & 224 & 25 & 243 & 237 \\
\hline Bod & & 247 & & & 229 & & 226 & 213 & 25 & 219 & 216 \\
\hline & 228 & 246 & 21 & 221 & 217 & & 199 & 207 & 13 & 186 & 184 \\
\hline & 117 & 118 & & & $113 ?$ & & $121 ?$ & 115 & $21 ?$ & $95 ?$ & $95 ?$ \\
\hline Dor & 2 & 225 & & & & & 194 & & 13 & 184 & 176 \\
\hline Dor & & 378 亡 & $355 \pm$ & 355 & 6 & & 350 & 345 & 65 & 357 & 349 \\
\hline & & 343 & 343 & & 34 & & 338 & $342 \pm$ & 39 & 338 & 334 \\
\hline & & 204 & & 212 & 200 & & 211 & 201 & 13 & 215 & 207 \\
\hline & 133 & 134 & 143 & 137 & 132 & & 149 & 129 & 49 & 136 & 134 \\
\hline Caud & 155 & 167 & 168 & 160 & 163 & 168 & 166 & 162 & 155 & 171 & 164 \\
\hline Least & 106 & 105 & 102 & 107 & $103 ?$ & $100 ?$ & $93 ?$ & 101 & 97 & $82 ?$ & 77 \\
\hline tal, least bony & & & & & & & & & & & \\
\hline & 65 & 72 & 76 & 70 & 66 & 71 & 66 & 64 & 70 & 70 & 69 \\
\hline & 79 & 76 & 77 & & 81 & 79 & 79 & & 82 & 82 & 79 \\
\hline & 64 & 61 & 62 & 60 & 61 & 64 & 64 & 66 & 64 & 66 & 65 \\
\hline & 50 & 46 & 54 & 50 & $51 ?$ & 54 & $?$ & 56 & $57 ?$ & 57 & 57 \\
\hline & 206 & 200 & 199 & 209 & 199 & 204 & 210 & 206 & 209 & 209 & 213 \\
\hline & 211 & 200 & 20 & 21 & & & 218 & 211 & 218 & 214 & 215 \\
\hline Dor: & 247 & 245 & 25 & 23 & & & 238 & 232 & 38 & & 232 \\
\hline & 128 & 133 & 12 & 132 & 133 & 133 & $132 ?$ & 130 & 125 & 126 & 128 \\
\hline Anal, d & 155 & 157 & 157 & 150 & 149? & 152 & 162 & & 172 & 140 & 155 \\
\hline & 68 & 64 & 63 & 67 & 71 & 66 & 66 & 6 & 75 & 66 & 72 \\
\hline Adipc & 86 & 87 & 7 & 81 & 78 & 85 & 91 & & 86 & 78 & 75 \\
\hline & 24 & 35 & 27 & 23 & 25 & 24 & 35 & 24 & 21 & 31 & $28 \pm$ \\
\hline & $213 \pm$ & 236 & 233 & $207 ?$ & $205 ?$ & 207? & 245 & 229 & $181 ?$ & & $171 \pm$ \\
\hline Pelvic, length. & 191 & 189 & 197 & 174 & $177 ?$ & 172 & 190 & 188 & 184 & $145 \pm$ & $136 ?$ \\
\hline
\end{tabular}




\section{LITERATURE CITED}

ALCOCK, ALFRed WHLIAM.

1890. Natural history notes from H. M. Indian marine survey steamer Investigator, Commander R. F. Hoskyn, R. N., commanding-No. 18. On the bathybial fishes of the Arabian Sea, obtained during the BoLIN, ROLF LING. season 1889-90. Ann. Mag. Nat. Hist., ser. 6, vol. 6, pp. 295-311.

1939. A review of the myctophid fishes of the Pacific coast of the United States and Lower California. Stanford Ichth. Bull., vol. 1, No. 4, pp. 89-156, figs. 1-29.

Chapman, Wilbert McLeod.

1939. Eleven new species and three new oceanic fishes collected by the International Fisheries Commission from the Northeastern Pacific. Proc. U. S. Nat. Mus., vol. 86, pp. 501-542, figs. 58-70.

Gregory, Winliam King, and Conrad, G. Miles.

1936. Pictorial phylogenies of deep sea Isospondyli and Iniomi. Copeia, 1936, No. 1, pp. 21-36, figs. 1-4.

JoHnson, JAMES YATE.

1863. Descriptions of flve new species of fishes obtained at Madeira. Proc. Zool. Soc. London, 1863, pp. 1-11, pl. 7.

Myers, George Sprague.

1946. On a recently proposed new family of deep-sea fishes (Barbourisiidae, Parr, 1945). Copeia, 1946, No. 1, pp. 41-42.

NoRman, JoHN RoxbRough.

1939. Fishes. Sci. Reports John Murray Exped., London, vol. 7, No. 1, pp. 1-116, figs. 1-41.

PARr, Albert Eme.

1928. Deepsea fishes of the order Iniomi from the waters around the Bahama and Bermuda Islands with annotated keys to the Sudidae, Myctophidae, Scopelarchidae, Evermannellidae, Omosudidae, Cetomimidae and Rondeletidae of the World. Bull. Bingham Oceanogr. Coll., vol. 3, art 3, pp. 1-193, figs. 1-43.

1945. Barbourisidae, a new family of deep-sea fishes. Copeia, 1945, No. 3, pp. 127-129, pl. 1.

Regan, Charles Tate.

1911. The anatomy and classification of the teleostean fishes of the order Iniomi. Ann. Mag. Nat. Hist., ser. 8, vol. 7, pp. 120-133, figs. 1-8. 

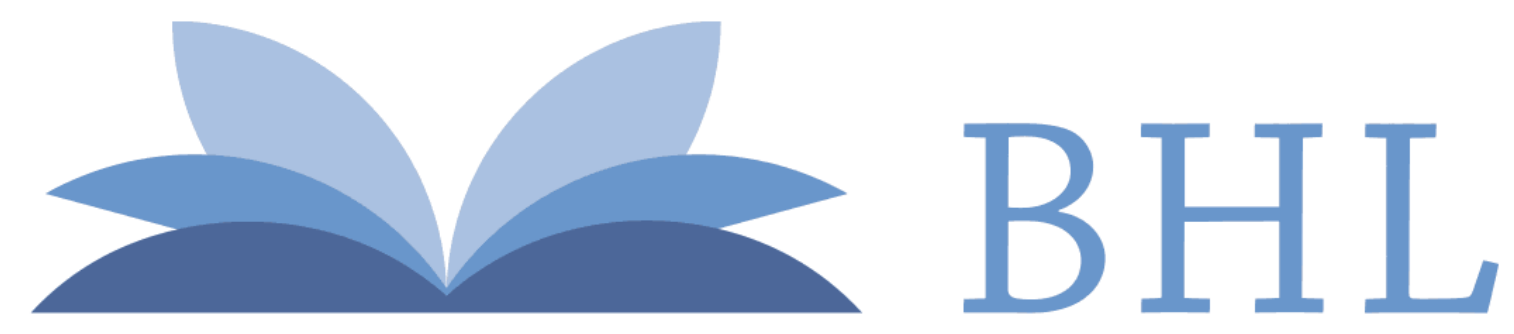

\section{Biodiversity Heritage Library}

Miller, Robert Rush. 1947. "A new genus and species of deep-sea fish of the family Myctophidae from the Philippine Islands." Proceedings of the United States National Museum 97(3211), 81-90.

https://doi.org/10.5479/si.00963801.97-3211.81.

View This Item Online: $\underline{\text { https://www.biodiversitylibrary.org/item/53540 }}$

DOI: https://doi.org/10.5479/si.00963801.97-3211.81

Permalink: https://www.biodiversitylibrary.org/partpdf/52632

\section{Holding Institution}

Smithsonian Libraries

\section{Sponsored by}

Smithsonian

\section{Copyright \& Reuse}

Copyright Status: Public domain. The BHL considers that this work is no longer under copyright protection.

This document was created from content at the Biodiversity Heritage Library, the world's largest open access digital library for biodiversity literature and archives. Visit BHL at https://www.biodiversitylibrary.org. 